\title{
Rhyolitic (Micrographic Granite) Igneous Clasts from Ancient Mars in the Martian Meteorite Northwest Africa 8171
}

M. LINDNER ${ }^{1 \dagger}$, A. K. SCHMITT ${ }^{2}$, A. N. KROT ${ }^{3}$ AND F. E. BRENKER $^{1,3}$

${ }^{1}$ Department of Geosciences, Goethe University Frankfurt, 60438 Frankfurt, Germany, ${ }^{\dagger}$ s7493063@stud.unifrankfurt.de

${ }^{2}$ Institute of Earth Sciences, Heidelberg University, 69120 Heidelberg, Germany

${ }^{3}$ Hawai'i Institute of Geophysics and Planetology, University of Hawai'i at Mānoa, Honolulu, HI 96822, USA

We report rhyolitic igneous rock clasts and $\mathrm{SiO}_{2}$ grains found within a proto-breccia clast (PBC-01) in the Martian polymict breccia Northwest Africa 8171 (NWA 8171). Protobreccia clasts show a brecciation history prior to incorporation into a final regolith breccia [1]. PBC-01 is depleted in $\mathrm{Mg}$ compared to the typical NWA 8171 groundmass. It texturally resembles a rapidly crystallized melt and consists of crystal fragments, glassy melt chards, and a low number of igneous clasts inter alia.

Numerous crystal fragments are $\mathrm{SiO}_{2}$ grains showing a sub-angular to sub-rounded shape; the largest 12 fragments are $40-170 \mu \mathrm{m}$ in apparent diameter. Two igneous rock clasts (clast 8 and clast $9,220 \times 110 \mu \mathrm{m}$ and $30 \times 20 \mu \mathrm{m}$, respectively) are of rhyolitic composition. We focussed our study on the clast 8 because of its larger size and higher mineral variability. It consists mainly of two potassic feldspars $\left(\mathrm{An}_{11} \mathrm{Ab}_{82} \mathrm{Or}_{7-}\right.$ $\mathrm{An}_{0} \mathrm{Ab}_{27} \mathrm{Or}_{73}$ ) forming a micrographic intergrowth with $\alpha$ quartz; minor phases include acicular chlorapatite, a euhedral Fe-oxide grain, and small zircon crystals. Three zircon grains ((z1, z2, z3), 1-4 $\mu \mathrm{m}$ in size), were used for in situ $\mathrm{U}-\mathrm{Pb}$ dating with SIMS. This yielded two data points (z1 and z2) which fall in row with reported zircon data for paired samples NWA 7533 and NWA 7034 [2,3]. The discordia intercepts at $4289 \pm 970 \mathrm{Ma}$ and $1397 \pm 410 \mathrm{Ma}(2 \sigma$ error). $\mathrm{z} 3$ plots off that discordia, with lower ${ }^{206} \mathrm{~Pb} /{ }^{238} \mathrm{U}$ and ${ }^{205} \mathrm{~Pb} /{ }^{235} \mathrm{U}$ values.

We tentatively interprete the $\mathrm{U}-\mathrm{Pb}$ data in the sense, that $\mathrm{z} 1$ and z2 plot on a similar discordia as previously measured zircons by $[2,3]$. z3 was likely affected by a Pb-loss event at $<<1500 \mathrm{Ma}$. The data suggest that evolved melts were already present on ancient Mars. The co-occurrence of $\mathrm{SiO}_{2}$ grains might suggest that these melts crystallized in larger bodies, opposed to the rhyolitic melts reported in [4]. Their erosional products where present within the Martian regolith when the PBC-01 lithology formed.

[1] Santos A. R. et al. (2015) GCA 157, 56-85; [2] Humayun M. et al. (2013) Nature 503, 513-516; [3] Yin Q.-Z. et al. (2014) LPSC XLV Abstract \#1320; [4] Filiberto J. et al. (2014) Am. Min. 99, 601-606. 